\title{
Secteur 8 : ouest du département des Vosges
}

Gilbert Salvini

\section{Q OpenEdition \\ Journals}

Édition électronique

URL : http://journals.openedition.org/adlfi/8812

ISSN : 2114-0502

Éditeur

Ministère de la culture

Référence électronique

Gilbert Salvini, "Secteur 8 : ouest du département des Vosges », ADLFI. Archéologie de la France Informations [En ligne], Lorraine, mis en ligne le 01 mars 2001, consulté le 25 avril 2019. URL : http:// journals.openedition.org/adlfi/8812

Ce document a été généré automatiquement le 25 avril 2019

(c) Ministère de la Culture et de la Communication, CNRS 


\title{
Secteur 8 : ouest du département des Vosges
}

\author{
Gilbert Salvini
}

Identifiant de l'opération archéologique : F1354200100074

Date de l'opération : 2001 (PA)

$1 \quad \operatorname{ESLEY}(88)$, l'Hembotin

2 Dans les céréales en herbe, apparait en palimpseste des structures polygonales périglaciaires des alluvions sous-jacentes, perturbées au cours de la dernière glaciation.

3 MAREY (88), Fond des Pommiers

4 Phénomène géologique révélé par l'humidité qui a hâté la croissance de la luzerne sur un plateau karstique. On distingue les diaclases qui marquent l'effondrement du rebord de plateau et les dolines fermées par les sédiments.

5 SALVINI Gilbert

\section{INDEX}

Index géographique : Lorraine, Vosges (88)

operation Prospection aérienne (PA)

Thèmes : alluvion, céréale, flore, géomorphologie, glaciation 
AUTEURS

GILBERT SALVINI 